\title{
Molten Tetrabutylammonium Bromide as Eco-Friendly Media for the Synthesis of Optically Active and Thermal Stable Polyamides under Microwave Irradiation
}

\author{
By Shadpour MALLAKPOUR* and Mehdi TAGHAVI
}

The present paper is an extension of microwave method describing the synthesis of optically active polyamides (PAs). The main focus of this work is the design of effective microwave method for preparing of optically active PAs. The diacid containing amino acid and 1,8-naphthalimide group was prepared in three steps. For the preparation of optically active polymers from this monomer the polycondensation reactions of diacid 7 with different aromatic and aliphatic diisocyanates was employed in the presence of a small amount of tetrabutylammonium bromide as ionic liquid media that acts as a primary microwave absorber and was compared with conventional heating. The resulting polymers were characterized using FT/IR, ${ }^{1} \mathrm{H}$ NMR, ${ }^{13} \mathrm{C}$ NMR, UV-vis spectroscopy, fluorimetry, specific rotation techniques and elemental analysis. Thermal properties of the resulting PAs were evaluated by thermogravimetric analysis and differential scanning calorimetry. The interpretation of kinetic parameters $(E, \Delta H, \Delta S$ and $\Delta G)$ of thermal decomposition stages have also been evaluated using Coats-Redfern and Dharwadkar-Kharkhanawala equations.

KEY WORDS: Green Chemistry / Optically Active Polymers / Ionic Liquids / Thermal Properties / Kinetic Study / Microwave-

Assisted Polycondensation /

Due to worsening of the environment, green chemistry has been receiving progressively more attention since the 1990 's. ${ }^{1,2}$ Hence, there is a great necessitate for the advancement of novel methodologies for polymerization using environmentally ecofriendly media and give sufficient solubility to polymerization which could replace the highly polar conventional and chlorinated solvents which are volatile, most of them flammable, toxic, quite hazardous and harmful. ${ }^{3-6}$ Ionic liquids (ILs) made of organic cations and suitable anions have attracted much recent consideration as solvents for chemistry because of the fact that they have melting points close or near to room temperature. The most of ILs are clear and colorless viscous liquid. ILs possess a distinctive array of physico-chemical properties that make them appropriate in numerous task-specific uses in which conventional solvents are non-applicable or ineffectually effective. Such properties comprise: high electrical conductivity, high thermal stability, large electrochemical window, low nucleophilicity and capability of providing weekly coordinating or noncoordinating environment, very good solvents properties for a broad diversity of inorganic, organic, organometallic and polymeric compounds. ${ }^{7-12}$ In some cases, the solubility of certain solutes in ILs can be some orders of magnitude higher than that in traditional solvents. However, the high cost of most room temperature ILs and apprehension about their toxicity has led researchers to find out the use of more benign salts in the molten state as useful alternatives. Recently, molten tetrabutylammonium bromide (TBAB) was used as a low toxic and cost-effective IL in a number of constructive synthetic transformations. ${ }^{13-15}$
The synthesis and application of optically active polymers have recently become the focus of greater attention because polymers with chiral structures are biologically very important. Most of the natural polymers are optically active and have special chemical activities such as catalytic properties that exist in proteins, enzymes, and genes. ${ }^{16-24}$

The application of microwave energy for the synthesis of organic compounds has been used since 1986. Microwave ovens are a feature of many households, but in the industrial world, microwave energy has been applied to several areas, including bulk food processing, the drying and curing of paper and wood products, the vulcanization of rubber and the drying of thermoplastics before extrusion. Also the mechanism of microwave heating is independent of the thermal conductivity, microwave heat the molecules directly through the interaction between microwave energy and molecular dipole moments of the monomers containing polar groups and ionic solvents that favor the absorption of microwaves and avoids the heattransfer rate problem encountered in conventional thermal heating. In polymer processing, to merge the advantages of microwave techniques and ILs for more sophisticated processing and fabrication of polymers several organic reactions such as acetylation, oligomerization, dimerization, polymerization and copolymerization reactions have been carried out in IL under microwave irradiation. ${ }^{25-34}$

Chromophoric polymers have been widely explored in the last decade due to their potential technological use in electronic devices and opto-electronic. Naphthalene structure as a chromophore gave special features such as bulky, rigid, 
moisture resistance and low coefficient of thermal expansion to polymer. Naphthalene has also been incorporated into the backbones of many polymers including PAs, polyesters, bismaleimides and etc. The amalgamation of naphthalene as a pendant group in a polymer chain has resulted in decreased crystallinity and enhanced solubility and thermal stability. ${ }^{35-38}$

Recently, much attention on high-performance polymers that have excellent thermal stability and solubility has provided researchers with the impetus that has led to the discovery of a variety of processable and thermostable polymers. PAs are one of the high-performance polymeric materials and are characterized by thermo oxidative stability and high thermal, good mechanical properties, and outstanding solvent resistance. However, poor solubility is a major problem for wide application of PAs, but these inherent problems have been dealt by many research efforts during the last decades by incorporation of alkyl or aryl substitution to decrease the hydrogen bonding at the amide linkage, symmetric/asymmetric bulky substitution in the aromatic rings, copolymerization, lateral substituents, nature of parent chain in the polymer forming monomeric units, noncoplanar biphenylene moieties, pendant phenyl group and flexible alkyl spacers into the PAs backbone. ${ }^{39-44}$

1,8-naphthalimide moieties have become a very actual class of organic luminophores, on the other hand polymers containing this functional group can be used as sensors for transition metal ions or protons whose sensor characteristics can be explained either by conformational changes in the macromolecules or by the collective transport properties. In this study, we wish to report a combination of microwave energy with ILs as reaction media under green conditions for the synthesis of optically active and photolabeling PAs containing 1,8-naphthalenedicarboxylic anhydride and S-valine as pendant moieties and compares it with classical heating solution polymerization. In another section of this research we set out to investigate kinetic study and thermal decomposition behavior of these PAs.

\section{EXPERIMENTAL}

\section{Materials}

Reagents were purchased from Fluka Chemical (Buchs, Switzerland), Aldrich Chemical (Milwaukee, WI) and RiedeldeHaen AG (Seelze, Germany). N,N-Dimethylacetamide (DMAc) and $N$-methyl-2-pyrrolidone (NMP) were dried over $\mathrm{BaO}$ and then were distilled under reduced pressure. 5Aminoisophthalic acid (6) was recrystallized from $\mathrm{H}_{2} \mathrm{O} / \mathrm{DMF}$ ( $N, N$-dimethylformamide) (4/1) mixture. 1,8-Naphthalenedicarboxylic anhydride was recrystallized from hot acetic anhydride. 1,4-Diazabicyclo[2.2.2] octane (DABCO) and tetrabutylammoniom bromide (TBAB) were purchased from Merck Co. and were used without further purification.

\section{Techniques}

${ }^{1} \mathrm{H}$ NMR $(500 \mathrm{MHz})$ spectra were recorded on a Bruker (Germany), Avance 500 instrument. FT/IR spectra were recorded on (Jasco-680, Japan) spectrophotometer. Spectra of solids were carried out using $\mathrm{KBr}$ pellets. All melting points were taken with a Gallenham melting point apparatus. The microwave apparatus used for the polycondensation was a Samsung (Seoul, South Korea) microwave oven $(2450 \mathrm{MHz}$ and $900 \mathrm{~W}$ ). Inherent viscosities were measured by standard procedure using a Cannon Fenske Routine viscometer. Quantitative solubility was determined using $0.05 \mathrm{~g}$ of the polymer in $1 \mathrm{~mL}$ of solvent. Elemental analyses were performed by Research Institute of Polymer and Petrochemical of Iran (IPPI). Fluorescence and UV-vis spectra were recorded on a spectrofluorometer, JASCO, FP-750 and UV/Vis/NIR spectrophotometer, JASCO, V-570, respectively. Thermal gravimetric analysis (TGA) data for polymers were taken on a TGA-Perkin Elmer (Pyris 1) at a heating rate of $10^{\circ} \mathrm{C}$ min under $\mathrm{N}_{2}$ atmosphere and differential scanning calorimetry (DSC) data were recorded on a DSC-PL-1200 instrument under $\mathrm{N}_{2}$ atmosphere by IPPI.

\section{Monomer Synthesis}

5-[3-methyl-2-(1,8-naphthalimidyl)butanoylamino]isophthalic acid (6) was prepared (Scheme 1) according to our previous work. $^{45}$

\section{Polymer Synthesis}

Method I. Polymerization of diacid 7 with diisocyanates in TBAB as an IL media under conventional heating.

A typical preparation of PA9 is as follow: A $25 \mathrm{~mL}$ roundbottomed flask equipped with a mechanical stirrer was charged with a mixture of compound $7\left(0.10 \mathrm{~g}, 2.17 \times 10^{-4} \mathrm{~mol}\right)$, triethylamine (TEA) $\left(0.02 \mathrm{~mL}, 1.80 \times 10^{-4} \mathrm{~mol}\right)$ and TBAB $\left(0.30 \mathrm{~g}, 9.42 \times 10^{-4} \mathrm{~mol}\right)$ was ground until a powder was formed then toluylene-2,4-diisocyanate TDI (9) (0.04 g, $\left.2.17 \times 10^{-4} \mathrm{~mol}\right)$ was added. The mixture, blanketed by nitrogen, was stirred and heated to $120^{\circ} \mathrm{C}$ for $12 \mathrm{~h}$. The viscous final solution was poured in $30 \mathrm{~mL}$ of methanol to precipitate the polymer. The white solid was washed thoroughly with water. The resulting polymer was dried in a vacuum oven at $80^{\circ} \mathrm{C}$, yielded $0.12 \mathrm{~g}(86 \%)$ of PA9. All others PAs were also synthesized with a similar procedure, using pyridine (Py), tributylamine (TBA), DABCO, DBTDL as catalysts and without any catalyst, respectively.

Method II. Polymerization of diacid 7 with diisocyanates in $\mathrm{TBAB}$ as an IL media under microwave irradiation.

The PAs were prepared by the following general procedure (taking PA21 as an example): Into a porcelain dish, TBAB $\left(0.23 \mathrm{~g}, 6.98 \times 10^{-4} \mathrm{~mol}\right)$ and monomer $7\left(0.10 \mathrm{~g}, 2.36 \times 10^{-4}\right.$ mol) were added. After the mixture was completely ground, DBTDL $\left(0.02 \mathrm{~g}, 3.01 \times 10^{-5} \mathrm{~mol}\right)$ was added and the mixture was ground for $10 \mathrm{~min}$, then TDI (9) $\left(0.04 \mathrm{~g}, 2.36 \times 10^{-4} \mathrm{~mol}\right)$ was added and the mixture was ground again for additional $2 \mathrm{~min}$. The reaction mixture was irradiated in a microwave oven for 1 min then it was cooled and irradiated for 30 more $\mathrm{s}$ at $100 \%(900 \mathrm{~W})$ of its power level. The resulting product was isolated by the addition of $30 \mathrm{~mL}$ of methanol. It was then filtered off and dried at $80{ }^{\circ} \mathrm{C}$ for $7 \mathrm{~h}$ in vacuum, this yielded $0.13 \mathrm{~g}(89 \%)$ of white PA21. The above polymerization was 

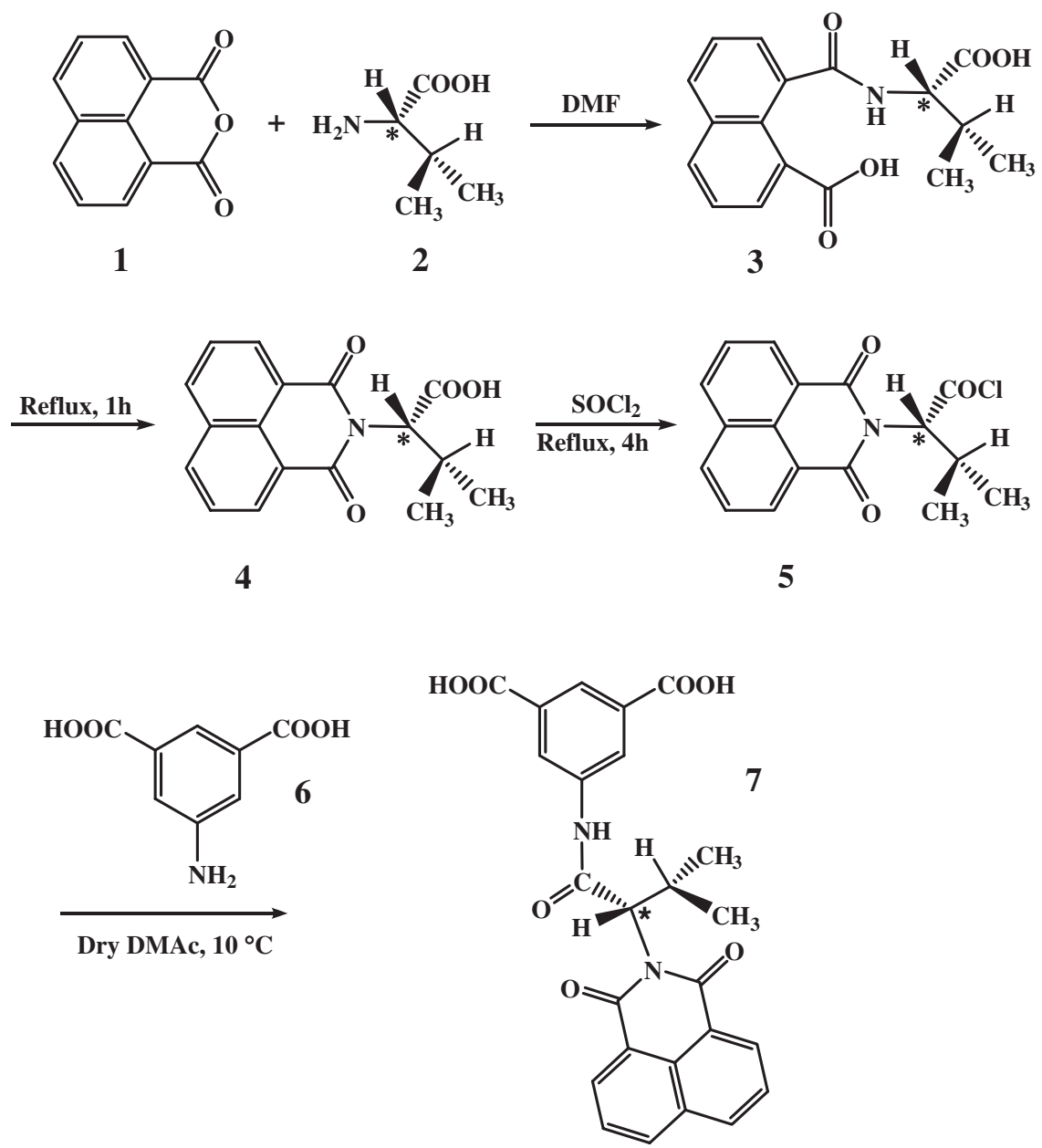

Scheme 1.

also repeated and the reaction mixture was irradiated in a microwave oven using Py, TEA, TBA and DABCO as catalysts, and without any catalyst, respectively. For each method, the optimized reaction conditions according to reaction time and reaction catalysts were selected for the polymerization of diacid monomer 7 with other diisocyanates such as 4,4'-methylenebis(phenyl isocyanate) MDI (8), isophorone diisocyanate IPDI (10) and hexamethylene diisocyanate HDI (11).

PA2. FT/IR (KBr, cm ${ }^{-1}$ ): 3317 (w), 3109 (w), 2965 (w), 1702 (m), 1662 (s), 1590 (s), 1509 (s), 1436 (w), 1409 (m), 1379 (m), $1340(\mathrm{~m}), 1312(\mathrm{~m}), 1238(\mathrm{~m}), 1200(\mathrm{w}), 1103(\mathrm{w}), 1018(\mathrm{w})$, 909 (w), 845 (w), 781 (w), 754 (w). ${ }^{1} \mathrm{H}$ NMR $(500 \mathrm{MHz}$, DMSO- $\left.d_{6}\right): \delta 0.73\left(\mathrm{~d}, 3 \mathrm{H}, \mathrm{CH}_{3}, J=5.05 \mathrm{~Hz}\right), 1.24(\mathrm{~d}, 3 \mathrm{H}$, $\left.\mathrm{CH}_{3}, J=4.90 \mathrm{~Hz}\right), 2.84(\mathrm{~m}, 1 \mathrm{H}, \mathrm{CH}), 3.87\left(\mathrm{~s}, 2 \mathrm{H}, \mathrm{CH}_{2}\right)$, $5.31(\mathrm{~d}, 1 \mathrm{H}, \mathrm{CH}, J=8.35 \mathrm{~Hz}), 7.19(\mathrm{~d}, 2 \mathrm{H}, \mathrm{CH}, J=7.20 \mathrm{~Hz})$, $7.66(\mathrm{~d}, 2 \mathrm{H}, \mathrm{CH}, J=7.40 \mathrm{~Hz}), 7.91(\mathrm{~s}, 2 \mathrm{H}, \mathrm{CH}), 8.14$ $(\mathrm{s}, 1 \mathrm{H}, \mathrm{CH}), 8.26(\mathrm{~s}, 2 \mathrm{H}, \mathrm{CH}), 8.54(\mathrm{dd}, 2 \mathrm{H}, \mathrm{CH}$, $\left.J_{1}=16.05 \mathrm{~Hz}, J_{2}=6.60 \mathrm{~Hz}\right), 9.95(\mathrm{~s}, 1 \mathrm{H}, \mathrm{NH}), 10.35(\mathrm{~s}$, $1 \mathrm{H}, \mathrm{NH})$. UV (DMF): $\lambda_{\max }(\varepsilon) 264$ (40833.33), $335 \mathrm{~nm}$ (20416.3 $\left.\mathrm{L} \mathrm{mol}^{-1} \mathrm{~cm}^{-1}\right)$.

PA8. FT/IR $\left(\mathrm{KBr}, \mathrm{cm}^{-1}\right): 3317(\mathrm{~m}), 3073(\mathrm{~m}), 2955(\mathrm{~m})$, 2924 (s), 2850 (s), 1707 (m), 1665 (s), 1588 (s), 1554 (s), 1432 (s), $1377(\mathrm{~m}), 1343(\mathrm{~m}), 1281(\mathrm{w}), 1239(\mathrm{w}), 1188(\mathrm{w}), 1153$ (w), 1108 (m), 1072 (m), 1027 (w), 909 (s), 842 (s), 780 (m), 747 (s), 712 (s), 679 (w), 618 (w), 548 (w), 495 (w). Elemental analysis calculated for $\mathrm{C}_{35} \mathrm{H}_{37} \mathrm{~N}_{4} \mathrm{O}_{5} \quad(593.69 \mathrm{~g} / \mathrm{mol}): \mathrm{C}$, $70.81 \%$; H, 6.28\%; N, 9.44\%. Found: C, 70.64\%; H, 6.31\%; $\mathrm{N}, 9.37 \%$. UV (DMF): $\lambda_{\max }(\varepsilon) 264$ (16527.78), $335 \mathrm{~nm}$ (20416.3 $\left.\mathrm{L} \mathrm{mol}^{-1} \mathrm{~cm}^{-1}\right)$.

PA12. FT/IR $\left(\mathrm{KBr}, \mathrm{cm}^{-1}\right)$ : 3305 (s), 3070 (w), 2921 (s), 2851 (s), 1702 (s), 1665 (s), 1633 (s), 1589 (m), 1541 (s), 1466 (w), 1433 (w), 1378 (m), 1342 (m), 1276 (w), 1235 (m), 1185 (w), $1107(\mathrm{w}), 1028(\mathrm{w}), 934(\mathrm{w}), 909(\mathrm{w}), 844(\mathrm{w}), 779(\mathrm{~m}), 744$ (w), 687 (w), 587 (w), 541 (w), 497 (w), 476 (w). ${ }^{1} \mathrm{H}$ NMR $\left(500 \mathrm{MHz}, \mathrm{DMSO}-d_{6}\right): \delta 0.71\left(\mathrm{~d}, 3 \mathrm{H}, \mathrm{CH}_{3}, J=5.17 \mathrm{~Hz}\right), 1.23$ $\left(\mathrm{d}, 3 \mathrm{H}, \mathrm{CH}_{3}, J=5.59 \mathrm{~Hz}\right), 1.22-1.31\left(\mathrm{~m}, 12 \mathrm{H}, \mathrm{CH}_{2}\right), 2.82(\mathrm{~m}$, $1 \mathrm{H}, \mathrm{CH}, J=6.40 \mathrm{~Hz}), 5.27(\mathrm{~d}, 1 \mathrm{H}, \mathrm{CH}, J=8.06 \mathrm{~Hz}), 8.00(\mathrm{~s}$, $2 \mathrm{H}, \mathrm{CH}), 8.11(\mathrm{~s}, 1 \mathrm{H}, \mathrm{CH}), 8.41(\mathrm{~s}, 2 \mathrm{H}, \mathrm{CH}), 8.57(\mathrm{t}, 4 \mathrm{H}, \mathrm{CH}$, $J=11.18 \mathrm{~Hz}), 9.77$ (s, 2H, NH), 9.85 (s, 1H, NH). UV (DMF): $\lambda_{\max }(\varepsilon) 264$ (13611.11), $335 \mathrm{~nm}\left(20416.3 \mathrm{~L} \mathrm{~mol}^{-1} \mathrm{~cm}^{-1}\right)$.

PA22. FT/IR (KBr, cm $\left.{ }^{-1}\right)$ : 3311 (s), 3115 (w), 2922 (s), 2851 (s), 1714 (s), 1663 (s), 1654 (s), 1587 (m), 1560 (s), 1436 (w), 1379 (m), 1347 (m), 1269 (w), 1239 (m), 1184 (w), 1135 (w), 1106 (w), 1024 (w), 903 (m), 842 (w), 778 (s), 746 (w), 685 (w), 624 (w), 597 (w), 539 (w), 497 (w), 473 (w). Elemental 

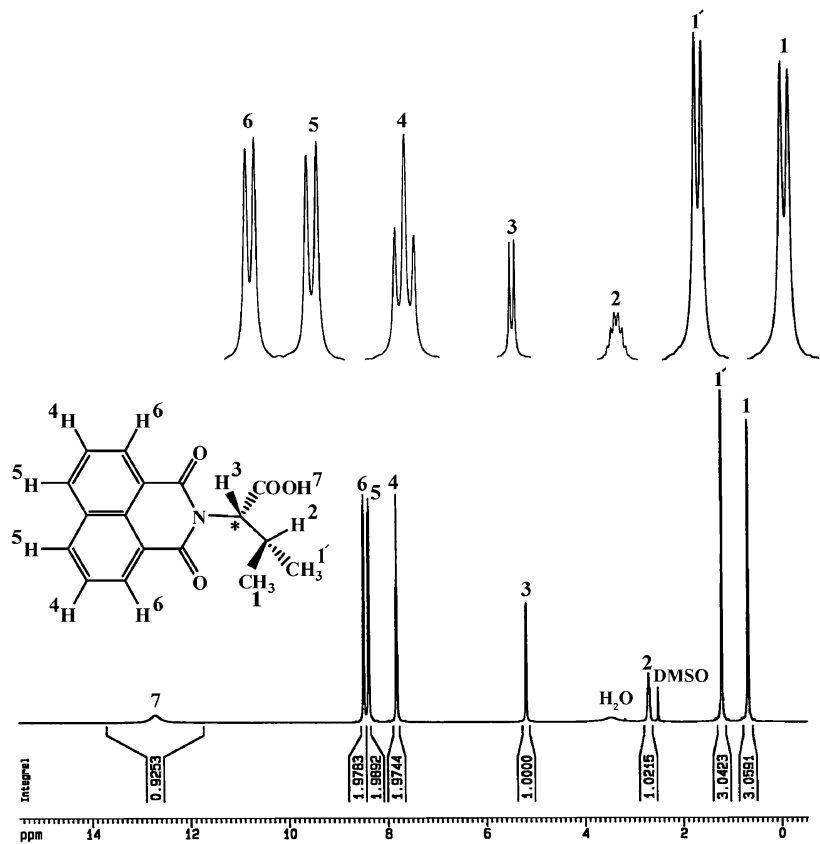

Figure 1. ${ }^{1} \mathrm{H}$ NMR $(500 \mathrm{MHz})$ spectrum of imide acid 4 in DMSO- $d_{6}$ at R.T.

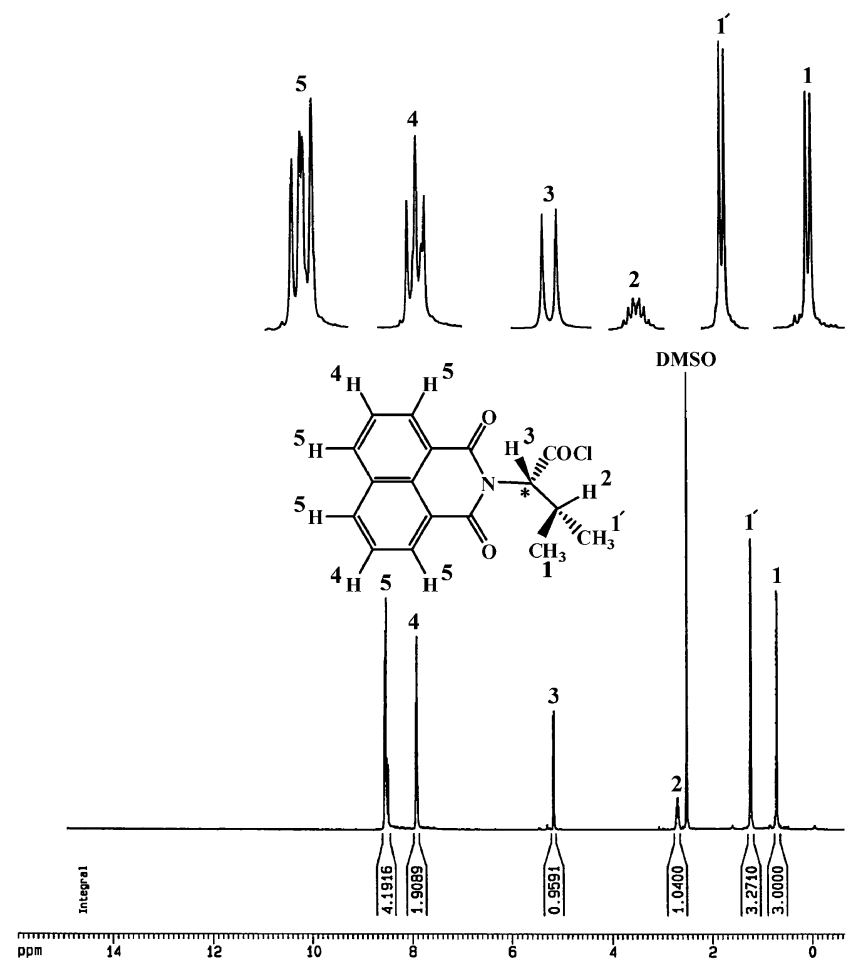

Figure 2. ${ }^{1} \mathrm{H}$ NMR $(500 \mathrm{MHz})$ spectrum of acid chloride 5 in DMSO- $d_{6}$ at R.T.

Table I. ${ }^{1} \mathrm{H}$ NMR and elemental analysis data of compounds 4,5 and 7

\begin{tabular}{|c|c|c|}
\hline Compound & \multicolumn{2}{|c|}{ Spectra data } \\
\hline 4 & $\begin{array}{l}{ }^{1} \mathrm{H} \text { NMR }\left(500 \mathrm{MHz}, \mathrm{DMSO}-d_{6}\right): \delta 0.67\left(\mathrm{~d}, 3 \mathrm{H}, \mathrm{CH}_{3}, J=6.83 \mathrm{~Hz}\right), \\
1.21\left(\mathrm{~d}, 3 \mathrm{H}, \mathrm{CH}_{3}, J=6.38 \mathrm{~Hz}\right), 2.70(\mathrm{~m}, 1 \mathrm{H}, \mathrm{CH}), 5.18(\mathrm{~d}, 1 \mathrm{H}, \\
\mathrm{CH}, J=9.13 \mathrm{~Hz}), 7.82(\mathrm{t}, 2 \mathrm{H}, \mathrm{CH}, \mathrm{Ar}-\mathrm{H}), 8.39(\mathrm{~d}, 2 \mathrm{H}, \mathrm{Ar}-\mathrm{H}, \\
J=8.16 \mathrm{~Hz}), 8.48(\mathrm{~d}, 2 \mathrm{H}, \mathrm{Ar}-\mathrm{H}, J=7.19 \mathrm{~Hz}), 12.71(\mathrm{~s}, 1 \mathrm{H}, \\
\mathrm{COOH}) \mathrm{ppm} .\end{array}$ & $\begin{array}{l}{ }^{13} \mathrm{C} \text { NMR }\left(500 \mathrm{MHz}, \mathrm{DMSO}-d_{6}\right): \delta 171.52(\mathrm{C}, \mathrm{COOH}), 164.17(\mathrm{C}, \\
\mathrm{C}=\mathrm{O}), 135.62(\mathrm{CH}, \mathrm{Ar}), 132.22(\mathrm{CH}, \mathrm{Ar}), 132.06(\mathrm{C}, \mathrm{Ar}), 128.16 \\
(\mathrm{CH}, \mathrm{C}, \mathrm{Ar}), 122.07(\mathrm{C}, \mathrm{Ar}), 58.82(\mathrm{CH}), 27.81(\mathrm{CH}), 23.00\left(\mathrm{CH}_{3}\right), \\
19.77\left(\mathrm{CH}_{3}\right) \mathrm{ppm} .\end{array}$ \\
\hline 5 & \multicolumn{2}{|c|}{$\begin{array}{l}{ }^{1} \mathrm{H} \text { NMR }\left(500 \mathrm{MHz}, \mathrm{DMSO}-d_{6}\right): \delta 0.70\left(\mathrm{~d}, 3 \mathrm{H}, \mathrm{CH}_{3}, J=6.93 \mathrm{~Hz}\right), 1.21\left(\mathrm{~d}, 3 \mathrm{H}, \mathrm{CH}_{3}, J=8.03 \mathrm{~Hz}\right), 2.69(\mathrm{~m}, 1 \mathrm{H}, \mathrm{CH}), 5.17(\mathrm{~d}, 2 \mathrm{H}, \mathrm{CH}, \\
J=9.21 \mathrm{~Hz}), 7.92(\mathrm{t}, 2 \mathrm{H}, \mathrm{CH}, \mathrm{Ar}-\mathrm{H}), 8.54\left(\mathrm{dd}, 2 \mathrm{H}, \mathrm{Ar}-\mathrm{H}, J_{1}=8.22 \mathrm{~Hz}, J_{2}=8.35 \mathrm{~Hz}\right) \mathrm{ppm} .\end{array}$} \\
\hline 7 & $\begin{array}{l}{ }^{1} \mathrm{H} \text { NMR }\left(500 \mathrm{MHz}, \mathrm{DMSO}-d_{6}\right): \delta 0.71\left(\mathrm{~d}, 3 \mathrm{H}, \mathrm{CH}_{3}, J=6.35 \mathrm{~Hz}\right), \\
1.23\left(\mathrm{~d}, 3 \mathrm{H}, \mathrm{CH}_{3}, J=5.90 \mathrm{~Hz}\right), 2.81(\mathrm{~m}, 1 \mathrm{H}, \mathrm{CH}), 5.30(\mathrm{~d}, 2 \mathrm{H}, \\
\mathrm{CH}, J=8.45 \mathrm{~Hz}), 7.91(\mathrm{t}, 2 \mathrm{H}, \mathrm{CH}, \mathrm{Ar}-\mathrm{H}), 8.13(\mathrm{~s}, 1 \mathrm{H}, \mathrm{CH}, \mathrm{Ar}-\mathrm{H}), \\
8.40(\mathrm{~s}, 2 \mathrm{H}, \mathrm{CH}, \mathrm{Ar}-\mathrm{H}), 8.52(\mathrm{~d}, 2 \mathrm{H}, \mathrm{Ar}-\mathrm{H}, J=8.06 \mathrm{~Hz}), 8.56(\mathrm{~d}, \\
2 \mathrm{H}, \mathrm{Ar}-\mathrm{H}, J=6.71 \mathrm{~Hz}), 9.95(\mathrm{~s}, 1 \mathrm{H}, \mathrm{NH}), 13.25(\mathrm{~s}, 1 \mathrm{H}, \mathrm{COOH}) \\
\text { ppm. }\end{array}$ & $\begin{array}{l}{ }^{13} \mathrm{C} \text { NMR }\left(500 \mathrm{MHz}, \mathrm{DMSO}-d_{6}\right): \delta 168.83(\mathrm{C}, \mathrm{C}=\mathrm{O}), 167.39(\mathrm{C}, \\
\mathrm{COOH}), 164.69(\mathrm{C}, \mathrm{C}=\mathrm{O}), 140.62(\mathrm{C}, \mathrm{Ar}), 135.50(\mathrm{CH}, \mathrm{Ar}), \\
132.29(\mathrm{CH}, \mathrm{Ar}), 132.24(\mathrm{C}, \mathrm{Ar}), 132.08(\mathrm{C}, \mathrm{Ar}), 128.52(\mathrm{CH}, \mathrm{Ar}), \\
128.22(\mathrm{C}, \mathrm{Ar}), 125.39(\mathrm{CH}, \mathrm{Ar}), 122.86(\mathrm{CH}, \mathrm{Ar}), 59.54(\mathrm{C}, \mathrm{Ar}), \\
27.58(\mathrm{CH}), 23.29\left(\mathrm{CH}_{3}\right), 19.47\left(\mathrm{CH}_{3}\right) \mathrm{ppm} .\end{array}$ \\
\hline
\end{tabular}

analysis calculated for $\mathrm{C}_{32} \mathrm{H}_{26} \mathrm{~N}_{4} \mathrm{O}_{5} \quad(546.57 \mathrm{~g} / \mathrm{mol})$ : $\mathrm{C}$, $70.32 \%$; H, 4.79\%; N, 10.25\%. Found: C, 69.74\%; H, 5.24\%; $\mathrm{N}, 10.17 \%$. UV (DMF): $\lambda_{\max }(\varepsilon) 264$ (96027.85), $335 \mathrm{~nm}$ (33348.40 $\left.\mathrm{L} \mathrm{mol}^{-1} \mathrm{~cm}^{-1}\right)$.

\section{RESULTS AND DISCUSSIONS}

\section{Monomer Synthesis}

Diacid 7 was prepared by the three-step process shown in Scheme 1. ${ }^{45}$ 1,8-Naphthalenedicarboxilic anhydride (1) was allowed to react with $\mathrm{S}$-valine (2) in DMF to provide imide acid 4. This compound was reacted with thionyl chloride to give corresponding acid chloride 5. The ${ }^{1} \mathrm{H}$ NMR spectra of compounds 4 and 5 showed all the peaks which were in good agreement with the proposed structure (Figures 1 and 2) and the results are shown in Table I. This acid chloride was reacted with 5-aminoisophthalic acid (6) and diacid 7 was obtained in good yield. The ${ }^{1} \mathrm{H}$ NMR spectrum of diacid 7 showed all the peaks which were in good agreement with the proposed structure of compound 7 (Table I). The chemical structures and purities of compounds 4,5 and 7 were proved with thin-layer chromatography, elemental analyses, FT/IR, specific rotation measurements, and ${ }^{1} \mathrm{H}$ NMR and ${ }^{13} \mathrm{C}$ NMR spectroscopy techniques. $^{45}$

\section{Polymer Synthesis}

Since the appearance of microwave assisted synthesis in 1986, this technique has been recognized as a well-known 


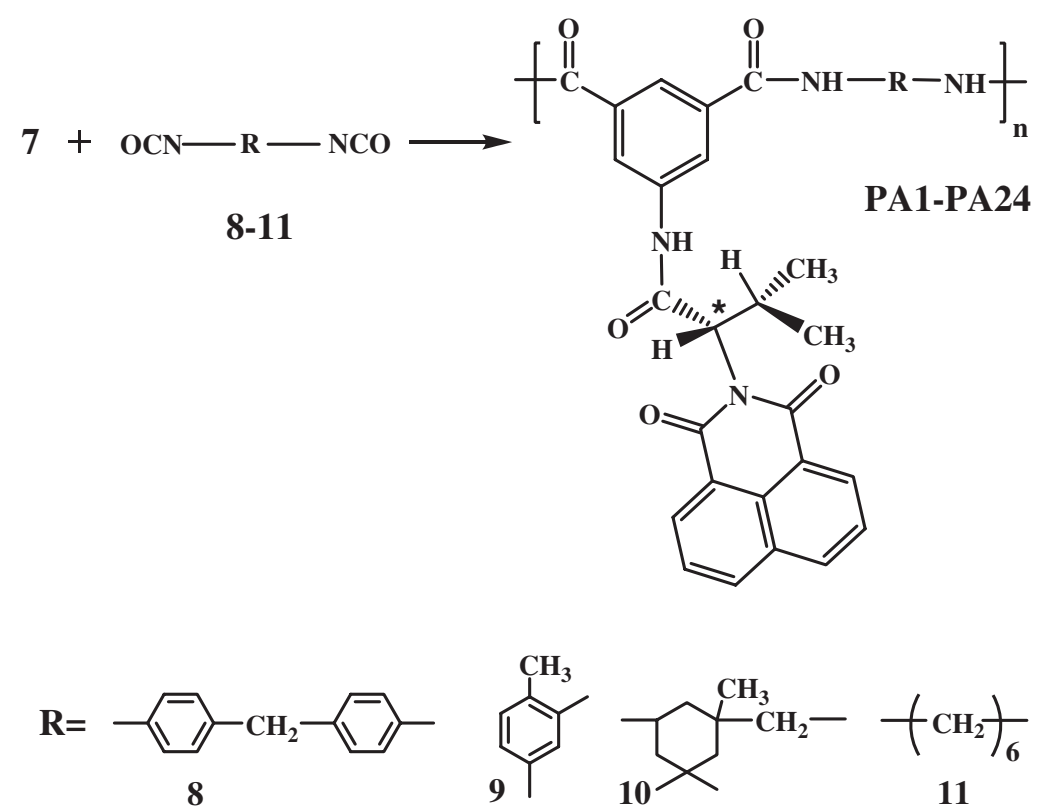

Scheme 2.

Table II. Reaction conditions for the polymerization of diacid 7 with different diisocyanates and some physical properties of PA1-PA12 prepared by method Ia

\begin{tabular}{|c|c|c|c|c|c|c|c|}
\hline Polymer & Diisocyanate & Catalyst & Non-solvent & $\begin{array}{l}\text { Yield } \\
(\%)\end{array}$ & $\begin{array}{c}\eta_{\text {inh }}{ }^{b} \\
(d L / g)\end{array}$ & {$[\boldsymbol{\alpha}]_{D}^{25 \mathrm{c}}$} & {$[\boldsymbol{\alpha}]_{H g}^{25 \mathrm{c}}$} \\
\hline PA1 & MDI & TEA & $\mathrm{MeOH} /$ Water & 82 & 0.49 & -30.14 & -44.34 \\
\hline PA2 & MDI & No cat & $\mathrm{MeOH} /$ Water & 72 & 0.43 & -34.22 & -48.92 \\
\hline PA3 & MDI & Py & $\mathrm{MeOH} /$ Water & 74 & 0.49 & -23.14 & -47.65 \\
\hline PA4 & MDI & DBTDL & $\mathrm{MeOH} /$ Water & 77 & 0.49 & -42.47 & -44.68 \\
\hline PA5 & MDI & TBA & $\mathrm{MeOH} /$ Water & 74 & 0.45 & -28.74 & -41.54 \\
\hline PA6 & MDI & DABCO & $\mathrm{MeOH} /$ Water & 74 & 0.44 & -44.87 & -59.32 \\
\hline PA7 & IPDI & TEA & Water & 83 & 0.43 & -24.17 & -36.14 \\
\hline PA8 & IPDI & No Cat & Water & 75 & 0.30 & -53.31 & -65.10 \\
\hline PA9 & TDI & TEA & Water & 86 & 0.49 & -35.97 & -38.01 \\
\hline PA10 & TDI & No Cat & Water & 86 & 0.49 & -23.01 & -24.98 \\
\hline PA11 & HDI & TEA & $\mathrm{MeOH} /$ Water & 68 & 0.45 & -53.19 & -64.26 \\
\hline PA12 & $\mathrm{HDI}$ & No Cat & $\mathrm{MeOH} /$ Water & 64 & 0.42 & -50.21 & -54.95 \\
\hline
\end{tabular}

${ }^{a}$ Method I: polymerization under conventional heating for $12 \mathrm{~h}$ at $120^{\circ} \mathrm{C}$. ${ }^{\mathrm{b}}$ Measured at a concentration of $0.5 \mathrm{~g} / \mathrm{dL}$ in DMF at $25^{\circ} \mathrm{C}$. ${ }^{\mathrm{C}} \mathrm{Measured}$ under conditions same as inherent viscosity.

method for reducing reaction time by several orders of magnitude and for increasing yields of product compared to conventional methods. The ILs are also suitable for microwave chemistry and it is expected that the high polarity of the IL makes it an efficient substrate for quick heating under microwave irradiation. We herein report an efficient, simplified and benign procedure for the preparation of PAs via direct polycondensation of diacid 7 with different aliphatic and aromatic diisocyanates $8-11$ in molten TBAB as green media (Scheme 2). The significant advantages of using IL and microwave irradiation are to avoid the use of volatile and toxic organic solvents and drastically reduction of reaction time. The polymerization reaction has been carried out both by thermal heating (method I) as well as microwave irradiation (method II) and the results shown in Tables II and III. The optimization of the reaction conditions for methods I and II by varying reaction time, microwave power level, period of heating and amount of IL was examined to provide polymers in high yields and inherent viscosities Table IV and Figure 3. The yields and inherent viscosities of the polymers obtained by microwave irradiation verses thermal heating are comparable with remarkable reduction in reaction time due to homogeneous heating throughout the reaction media by microwave irradiation as compared to convection currents in thermal heating. This methodology required only small amount of the IL to promote the polymerization. All of the PAs remained soluble in the reaction medium, thus permitting an increase their molecular weight and giving viscous solutions. Extended reaction time or higher power levels resulted in decreased yields and inherent viscosities for all PAs. This was due to decomposition of the reaction mixture. To avoid this trouble, the reactions were conducted with intermittent heating at a moderate power level with mixing. After the initial exposure for $60 \mathrm{~s}$ at $100 \%$ of power level $(900 \mathrm{~W})$ the reaction mixture 
Table III. Reaction conditions for the polymerization of diacid 7 with different diisocyanates and some physical properties of PA13-PA24 prepared by method II

\begin{tabular}{|c|c|c|c|c|c|c|c|}
\hline Polymer & Diisocyanate & Catalyst & Non-solvent & $\begin{array}{c}\text { Yield } \\
(\%)\end{array}$ & $\begin{array}{c}\eta_{\text {inh }}{ }^{b} \\
(d L / g)\end{array}$ & {$[\boldsymbol{\alpha}]_{D}^{25 c}$} & {$[\boldsymbol{\alpha}]_{H g}^{25}$} \\
\hline PA13 & MDI & TEA & $\mathrm{MeOH} /$ Water & 78 & 0.38 & -27.87 & -29.17 \\
\hline PA14 & MDI & No cat & $\mathrm{MeOH} /$ Water & 69 & 0.31 & -23.21 & -28.74 \\
\hline PA15 & MDI & Py & $\mathrm{MeOH} /$ Water & 81 & 0.33 & -26.18 & -47.50 \\
\hline PA16 & MDI & DBTDL & $\mathrm{MeOH} /$ Water & 88 & 0.38 & -40.00 & -44.05 \\
\hline PA17 & MDI & TBA & $\mathrm{MeOH} /$ Water & 74 & 0.38 & -22.11 & -46.23 \\
\hline PA18 & MDI & DABCO & $\mathrm{MeOH} /$ Water & 72 & 0.35 & -41.41 & -51.36 \\
\hline PA19 & IPDI & DBTDL & Water & 84 & 0.26 & -50.50 & -59.33 \\
\hline PA20 & IPDI & No Cat & Water & 84 & 0.22 & -54.15 & -56.18 \\
\hline PA21 & TDI & DBTDL & Water & 89 & 0.39 & -46.02 & -54.85 \\
\hline PA22 & TDI & No Cat & Water & 81 & 0.29 & -34.07 & -48.28 \\
\hline PA23 & HDI & DBTDL & $\mathrm{MeOH} /$ Water & 79 & 0.31 & -47.13 & -50.41 \\
\hline PA24 & $\mathrm{HDI}$ & No Cat & $\mathrm{MeOH} /$ Water & 77 & 0.27 & -31.74 & -55.16 \\
\hline
\end{tabular}

${ }^{a}$ Method II: The reaction mixture was irradiated in a microwave oven for $1 \mathrm{~min}$ then cooled and irradiated for $30 \mathrm{~s}$ again at $100 \%$ of its power level. ${ }^{\mathrm{b}} \mathrm{Measured}$ at a concentration of $0.5 \mathrm{~g} / \mathrm{dL}$ in DMF at $25^{\circ} \mathrm{C}$. ${ }^{\mathrm{C}}$ Measured under conditions same as inherent viscosity.

Table IV. Optimization of reaction conditions for the preparation of PAs using microwave irradiation (method II)

\begin{tabular}{|c|c|c|c|c|c|c|}
\hline Polymer & $\begin{array}{c}\text { Microwave } \\
\text { power }\end{array}$ & $\begin{array}{l}\text { Reaction } \\
\text { time }\end{array}$ & $\begin{array}{c}\text { Yield } \\
(\%)\end{array}$ & $\begin{array}{c}\eta_{\text {inh }}{ }^{a} \\
(\mathrm{dL} / \mathrm{g})\end{array}$ & {$[\alpha]_{D}^{25 \mathrm{~b}}$} & {$[\alpha]_{D}^{25 \mathrm{~b}}$} \\
\hline PA14 & 100 & $60 \mathrm{~s}^{\mathrm{c}}$ & - & - & - & - \\
\hline PA14 & 100 & $70 \mathrm{~s}$ & 48 & 0.19 & -30.02 & -32.12 \\
\hline PA14 & 100 & $80 \mathrm{~s}$ & 63 & 0.23 & -31.14 & -37.49 \\
\hline PA14 & 100 & $90 \mathrm{~s}$ & 71 & 0.27 & -27.54 & -27.89 \\
\hline PA14 & 100 & $100 \mathrm{~s}$ & 70 & 0.27 & -25.23 & -30.33 \\
\hline PA14 & 100 & $110 \mathrm{~s}$ & 66 & 0.28 & -26.66 & -29.87 \\
\hline PA14 & 100 & $120 \mathrm{~s}$ & 63 & 0.28 & -32.49 & -34.14 \\
\hline PA14 & 100 & $130 s^{c}$ & - & - & - & - \\
\hline PA14 & 100 & $60+30 s$ & 74 & 0.31 & -23.08 & -24.34 \\
\hline PA14 & 100 & $70+20 s$ & 69 & 0.30 & -23.14 & -24.77 \\
\hline PA14 & 100 & $80+10 s$ & 69 & 0.31 & -23.21 & -28.74 \\
\hline PA14 & 80 & $60 \mathrm{~s}^{\mathrm{c}}$ & - & - & - & - \\
\hline PA14 & 80 & $70 \mathrm{~s}$ & 46 & 0.19 & -24.30 & -27.47 \\
\hline PA14 & 80 & $80 \mathrm{~s}$ & 57 & 0.21 & -21.08 & -25.49 \\
\hline PA14 & 80 & $90 \mathrm{~s}$ & 62 & 0.22 & -24.71 & -24.97 \\
\hline PA14 & 80 & $100 \mathrm{~s}$ & 64 & 0.22 & -22.49 & -22.81 \\
\hline PA14 & 80 & $110 \mathrm{~s}$ & 65 & 0.22 & -21.11 & -23.97 \\
\hline PA14 & 70 & $60 s^{c}$ & - & - & - & - \\
\hline PA14 & 70 & $70 \mathrm{~s}$ & 42 & 0.18 & -26.41 & -28.06 \\
\hline PA14 & 70 & $80 s$ & 55 & 0.20 & -24.85 & -25.55 \\
\hline PA14 & 70 & $90 \mathrm{~s}$ & 62 & 0.21 & -24.70 & -24.78 \\
\hline PA14 & 70 & $100 \mathrm{~s}$ & 62 & 0.21 & -23.74 & -26.52 \\
\hline PA14 & 70 & $110 \mathrm{~s}$ & 62 & 0.20 & -22.14 & -23.02 \\
\hline
\end{tabular}

${ }^{\text {a }}$ Measured at a concentration of $0.5 \mathrm{~g} / \mathrm{dL}$ in DMF at $25^{\circ} \mathrm{C}$. ${ }^{\mathrm{b}}$ Measured under conditions same as inherent viscosity. ${ }^{\mathrm{c}}$ Decomposition occurred at higher power or extended irradiation time.

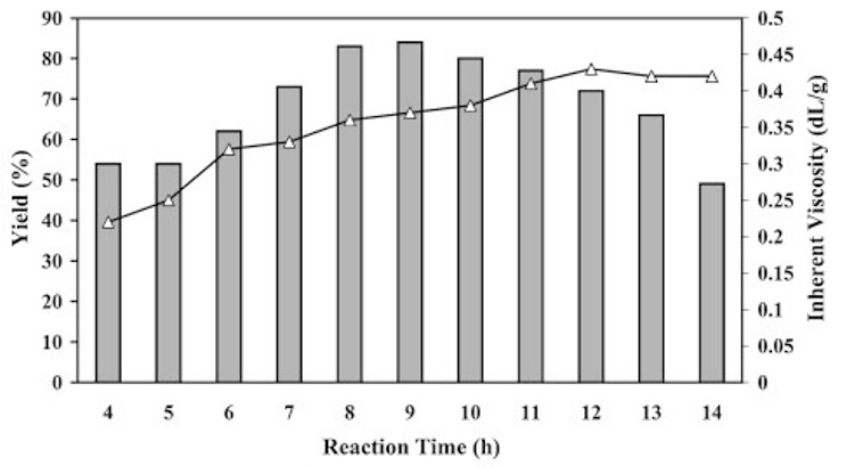

$\square$ Yield $九$ - Inherent Viscosity

Figure 3. The effect of reaction time on the inherent viscosity and yield of PA4 based on MDI by method I in the presence of DBTDL as a catalyst. taken out, mixed for 2 min and then heated at the same power level for an additional $30 \mathrm{~s}$. When the same experimental was conducted by conventional heating in the presence of TBAB it took $12 \mathrm{~h}$ for completion of polymerization reaction Tables II and III. On the other hand, a more homogeneous heating and outstanding rate quickening were observed under microwave irradiation. PAs made by different methods (Tables II and III) show different optical rotation and this is consistent for the all types of polymers made from different diisocyanates. These could be explained in terms of that optical rotation is highly dependent to the overall structure and regularity of the resulting polymer chains.

\section{Polymer Characterization}

The structure of polymers was implemented by means of 


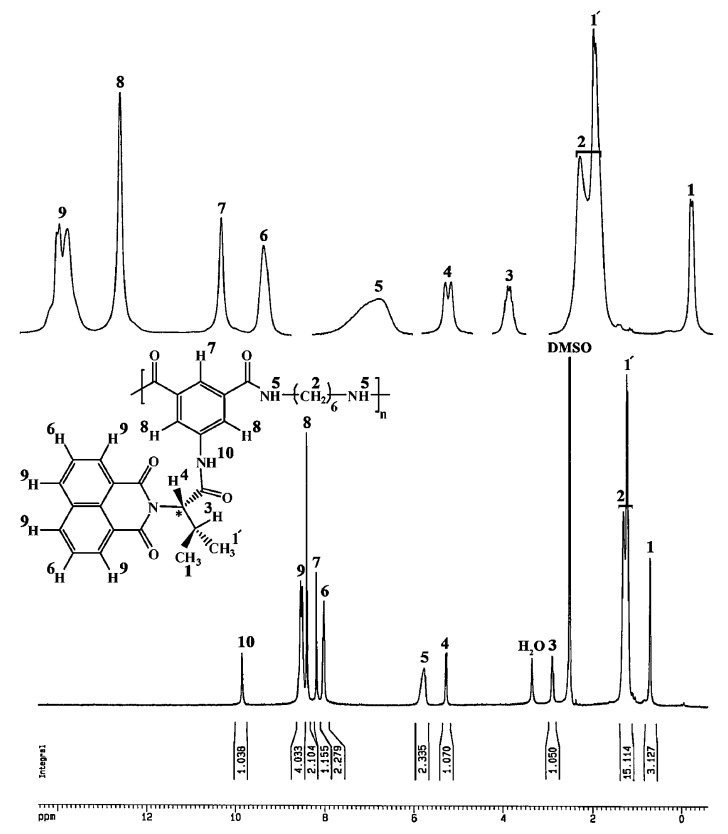

Figure 4. ${ }^{1} \mathrm{H}$ NMR $(500 \mathrm{MHz})$ spectrum of PA12 in DMSO- $d_{6}$ at R.T.

elemental analysis, FT/IR and ${ }^{1} \mathrm{H}$ NMR (500 MHz) spectroscopy techniques. The elemental analysis results were in good agreement with calculated percentages for carbon, hydrogen and nitrogen contents in PAs repeating unit. The FT/IR spectra of polymers show peak around $3300 \mathrm{~cm}^{-1}$ for the N-H bond. Main absorption bands at $1770-1650 \mathrm{~cm}^{-1}$ range were attributed to the carbonyl groups. A strong band corresponding to $\mathrm{C}-\mathrm{N}$ stretching can also be observed at $1340 \mathrm{~cm}^{-1}$. The two absorption bands at 2900 and $2850 \mathrm{~cm}^{-1}$ are related to the corresponding $\mathrm{C}-\mathrm{H}$ stretching vibration. The ${ }^{1} \mathrm{H}$ NMR spectra of polymers showed all peaks for aliphatic and aromatic protons which confirmed their structures. The resulting data are shown in Figures 4 and 5.

\section{Solubility Behavior of PAs}

The solubility of PAs was tested quantitatively in various solvents. All of the PAs, are readily soluble in organic solvents such as DMF, DMAc, dimethyl sulfoxide, NMP, Py and in $\mathrm{H}_{2} \mathrm{SO}_{4}$ at room temperature and are insoluble in solvents such as chloroform, tetrahydrofuran, methylene chloride, cyclohexane, acetone and water. Some polymers were partially soluble in methanol and ethanol and precipitated in $\mathrm{MeOH} /$ water. The excellent solubility of these PAs is due to the presence of bulky side group which prevent the packing of the macromolecules through hydrogen bonds between amides groups in the chain and thus facilitate the diffusion of solvent molecules among the polymer chains.

\section{Thermal Properties}

The thermal stability of some PAs was investigated by TGA/DTG and DSC techniques under a nitrogen atmosphere. Figure 6 shows the TGA curves for PA13, PA20, PA22 and PA23. Samples were heated up to $300^{\circ} \mathrm{C}$ at the rate of $20{ }^{\circ} \mathrm{C} \mathrm{min}^{-1}$ in $\mathrm{N}_{2}$, quenched to $-50{ }^{\circ} \mathrm{C}$ and return in order to obtain $T_{\mathrm{g}}$. Thermal stability of the polymers was studied based on 5 and $10 \%$ weight loss $\left(T_{5}, T_{10}\right)$ of the polymers and residue at $800{ }^{\circ} \mathrm{C}$ (char yield). Char yield can be used as criteria for evaluating limiting oxygen index (LOI) of the polymers in accordance with Van Krevelen and Hoftyzer equation. ${ }^{46}$ $\mathrm{LOI}=17.5+0.4 \mathrm{CR}$ where $\mathrm{CR}=$ char yield. All of the polymers had LOI values calculated based on their char yield at $800^{\circ} \mathrm{C}$ was higher than 28 . On the basis of LOI values, such macromolecules can be classified as self-extinguishing polymers. $T_{10}\left({ }^{\circ} \mathrm{C}\right)$, Char Yield, $T_{\mathrm{g}}$ and LOI of these polymers are in the range of $361-440^{\circ} \mathrm{C}, 45-47,124-186^{\circ} \mathrm{C}$ and $35-36$, respectively. According to these data it is clear that polymers based on TDI and MDI have better thermal stability and higher LOI as compared to other PAs. It could be pertained to aromatic and rigid structure of diisocyanates compare to aliphatic, flexible structure of diisocyanates. The results are given in Table $\mathrm{V}$ and Figure 6.

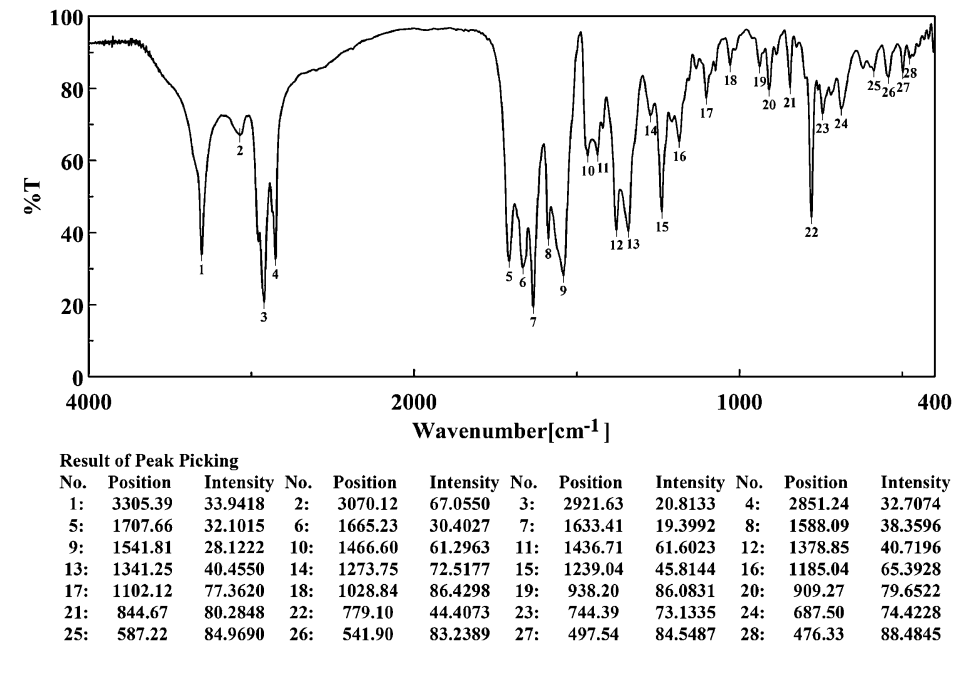

Figure 5. FT/IR spectrum of PA23. 


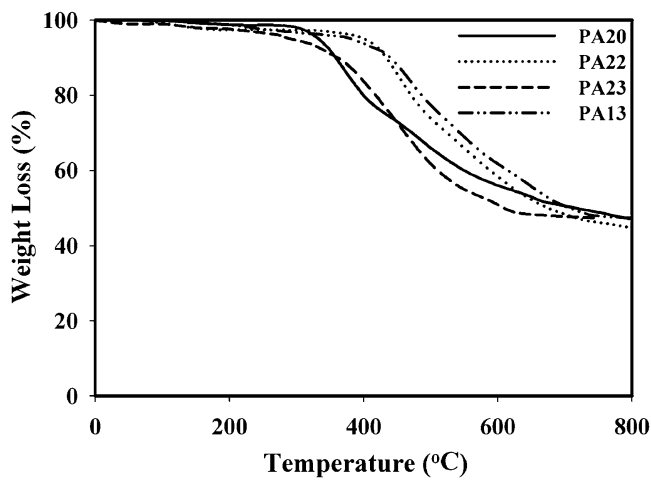

Figure 6. TGA thermograms of PA13, PA20, PA22 and PA23 under a nitrogen atmosphere at a heating rate of $10^{\circ} \mathrm{C} / \mathrm{min}$

Table V. Thermal properties of PA13, PA20, PA22 and PA23

\begin{tabular}{ccccccc}
\hline Polymer & $T_{5}\left({ }^{\circ} \mathrm{C}\right)^{\mathrm{a}}$ & $T_{10}\left({ }^{\circ} \mathrm{C}\right)^{\mathrm{b}}$ & $\begin{array}{c}\text { Char Yield } \\
(\%)^{\mathrm{c}}\end{array}$ & $T_{\mathrm{g}}\left({ }^{\circ} \mathrm{C}\right)^{\mathrm{d}}$ & DTG & LOI $^{\mathrm{e}}$ \\
\hline PA13 & 403 & 440 & 47 & 186 & 420 & 36.3 \\
PA20 & 336 & 365 & 45 & 124 & 364 & 35.5 \\
PA22 & 376 & 436 & 45 & 148 & 427 & 36.3 \\
PA23 & 289 & 361 & 47 & 135 & 375 & 35.5 \\
\hline
\end{tabular}

${ }^{\text {a }}$ Temperature at which $5 \%$ weight loss was recorded by TGA at a heating rate of $10^{\circ} \mathrm{C} / \mathrm{min}$. in a nitrogen atmosphere. ${ }^{\mathrm{b}} \mathrm{Temperature}$ at which $10 \%$ weight loss was recorded by TGA at a heating rate of $10^{\circ} \mathrm{C} / \mathrm{min}$. in a nitrogen atmosphere. ${ }^{C}$ Percentage weight of material left undecomposed after TGA analysis at a temperature of $800^{\circ} \mathrm{C}$ in a nitrogen atmosphere. ${ }^{d}$ Glass transition temperature was recorded at a heating rate of $20^{\circ} \mathrm{C} / \mathrm{min}$

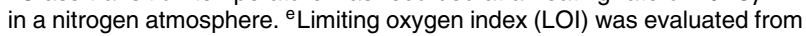
char yield obtained at $800^{\circ} \mathrm{C}$.

\section{UV-vis Absorption and Fluorescence Characteristics}

Polymers with fluorescent properties have been investigated in recent years. These polymers include chromophores in the backbone and polymers having chromophores as a pendant group. They are used as fluorescent labels and photoharvesters. Monomer 7 exhibited maximum UV-vis absorption at 264 and $335 \mathrm{~nm}$ in DMF solution because of the $\pi-\pi^{*}$ transitions of the aromatic chromophore (naphthalene). In comparison of UV-vis absorption of the resulting polymers with a series of segmented PAs containing naphthalene show that the later polymers gave absorption at 264 and $335 \mathrm{~nm}$ in DMF solution. ${ }^{37}$ The absorption and fluorescence spectra of $1.44 \times 10^{-5} \mathrm{M}$, DMF solution of the monomer 7, PA2, PA8 and PA12 were shown in Figures 7 and 8. For example, in the case of the PA2; when it was excited at $265 \mathrm{~nm}$, emission fluorescence wavelengths were observed at 342, 382 and $397 \mathrm{~nm}$, respectively. The emission fluorescence pattern of these polymers was also compared with the PAs and poly(urea-urethane)s which gave similar pattern. ${ }^{26,31,37}$ Because of these PAs have naphthalene functional group; they have potential to be used as photolabeling and photoresponsive materials. All of these compounds show almost similar UV-vis and fluorescence spectra pattern.

\section{Kinetic Study}

There are usually some doubts about the accuracy of data

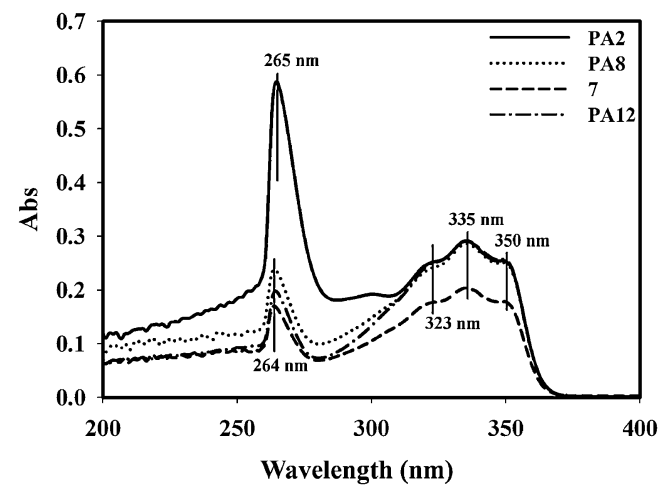

Figure 7. UV-vis spectrum of monomer 7, PA2, PA8 and PA12.

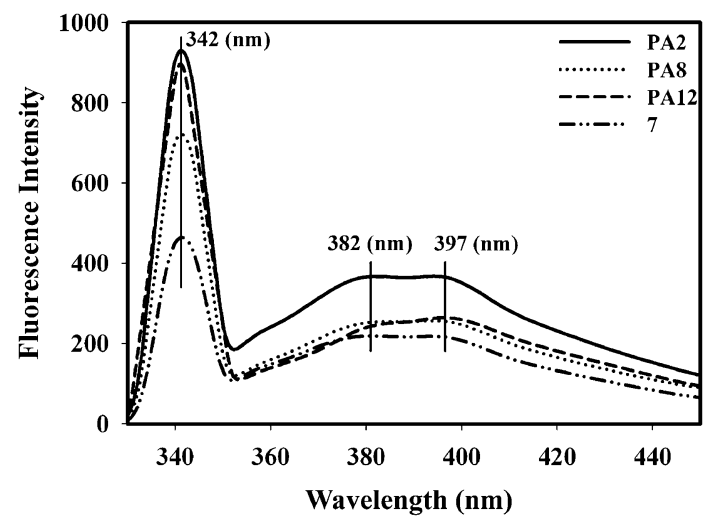

Figure 8. Fluorescence spectrum of monomer 7, PA2, PA8 and PA12.

obtained from the kinetic parameters which are estimated from the temperature integral. However, the most common application of these approximations is the determination of the activation energy and not the computation of the temperature integral. Thus in this paper, it is intended to perform a comparative study of the accuracy of such approximation to the temperature integral for the determination of the activation energy. In order to study the effect of different existing functional groups in the resulting PAs on their thermal stability, the thermal kinetic investigation was carried out using the Coats-Redfern (2) and Dharwadkar-Kharkhanawala (3) equations. ${ }^{46-52}$ The results are listed in Table VI. The calculating of thermodynamic data applied on the decomposition peak in PA13, PA20, PA22 and PA23.

$$
\int_{0}^{\alpha} \frac{\mathrm{d} \alpha}{(1-\alpha)^{\mathrm{n}}}=\frac{A}{\varphi} \int_{T_{1}}^{T_{2}} \exp \left(-\frac{E^{*}}{R T}\right) \mathrm{dt}
$$

For convenience of integration the lower limit $T_{1}$ is usually taken as zero. This equation upon integration gives the eq 2 :

$$
\begin{aligned}
& \ln \left[-\frac{\ln (1-\alpha)}{T^{2}}\right]=-\frac{E^{*}}{R T}+\ln \left[\frac{A R}{\varphi E^{*}}\right] \\
& \ln \{1 /(1-\alpha)\}=\left(E_{\mathrm{a}} / R T_{\mathrm{i}}^{2}\right)\left[100 \theta /\left(T_{\mathrm{f}}-T_{\mathrm{i}}\right)\right]+\mathrm{C} \\
& \Delta S=R \ln \left(\frac{A \mathrm{~h}}{\mathrm{~K}_{\mathrm{B}} T_{\mathrm{S}}}\right)
\end{aligned}
$$


Table VI. Kinetic parameters for the degradation of PAs determined using the Coats-Redfern ${ }^{1}$ and Dharwadkar-Kharkhanawala ${ }^{2}$ equations

\begin{tabular}{|c|c|c|c|c|c|c|}
\hline \multirow{2}{*}{ Polymer $^{1}$} & \multicolumn{5}{|c|}{ Parameter } & \multirow{2}{*}{$r$} \\
\hline & $E\left(\mathrm{~kJ} \mathrm{~mol}^{-1}\right)$ & $A\left(\mathrm{~s}^{-1}\right)$ & $\Delta S\left(\mathrm{~J} \mathrm{~mol}^{-1} \mathrm{~K}^{-1}\right)$ & $\Delta H\left(\mathrm{~kJ} \mathrm{~mol}^{-1}\right)$ & $\Delta G\left(\mathrm{~kJ} \mathrm{~mol}^{-1}\right)$ & \\
\hline PA13 (375-488) & 54.43 & 163.19 & -0.20 & 48.67 & 187.30 & 0.998 \\
\hline PA20 (310-415) & 57.55 & 165.93 & -0.20 & 52.29 & 178.92 & 0.999 \\
\hline PA22 (380-500) & 110.43 & 42.33 & -0.22 & 104.67 & 257.16 & 0.999 \\
\hline PA23 (310-430) & 60.70 & 148.93 & -0.20 & 55.31 & 184.94 & 0.998 \\
\hline \multirow{2}{*}{ Polymer $^{2}$} & \multicolumn{5}{|c|}{ Parameter } & \multirow{2}{*}{$r$} \\
\hline & $E\left(\mathrm{~kJ} \mathrm{~mol}^{-1}\right)$ & $A\left(\mathrm{~s}^{-1}\right)$ & $\Delta S\left(\mathrm{~J} \mathrm{~mol}^{-1} \mathrm{~K}^{-1}\right)$ & $\Delta H\left(\mathrm{~kJ} \mathrm{~mol}^{-1}\right)$ & $\Delta G\left(\mathrm{~kJ} \mathrm{~mol}^{-1}\right)$ & \\
\hline PA13 (375-488) & 63.54 & 190.51 & -0.20 & 57.77 & 196.40 & 0.997 \\
\hline PA20 (310-415) & 58.07 & 156.77 & -0.20 & 52.81 & 179.44 & 0.999 \\
\hline PA22 (380-500) & 96.31 & 92.46 & -0.21 & 90.55 & 236.11 & 0.997 \\
\hline PA23 (310-430) & 63.76 & 172.98 & -0.20 & 58.37 & 188.00 & 0.997 \\
\hline
\end{tabular}

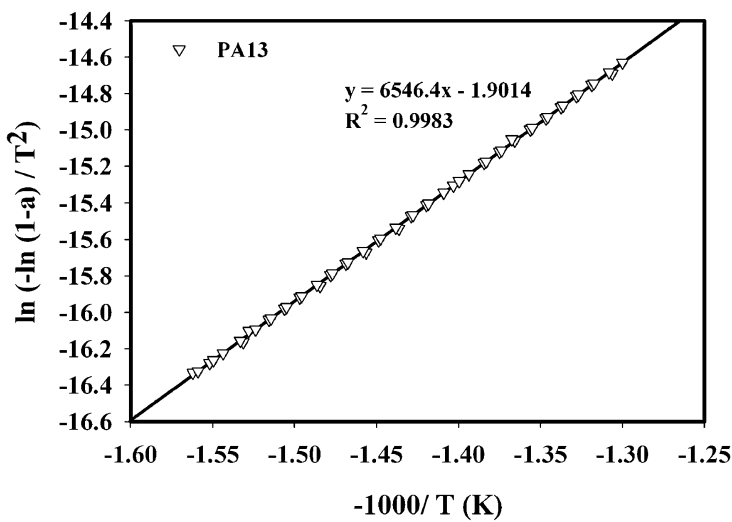

Figure 9. Plot of $\ln \left[-\ln (1-\alpha) / T^{2}\right]$ against $-1000 / T$ for PA13.

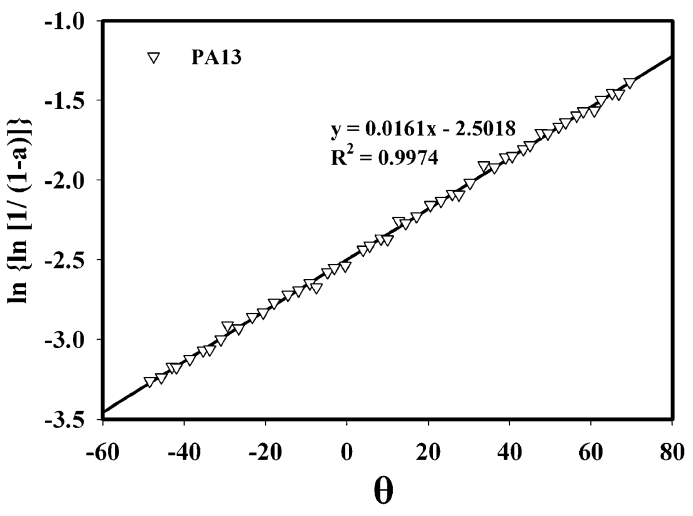

Figure 10. Plot of $\ln \{\ln [1 /(1-\alpha)]\}$ against $\theta$ for PA13.
Where $\alpha$ and $\varphi$ are the fraction of the sample decomposed at time $t$ and the linear heating rate, respectively. $R$ is the gas constant, $E$ is the activation energy in $\mathrm{kJ} \mathrm{mol}^{-1}, T_{\mathrm{i}}=$ temperature of inflection of the reaction, $T_{\mathrm{f}}=$ temperature of completion of the reaction, $\theta=\left(T-T_{\mathrm{s}}\right)$, difference between $T_{\mathrm{s}}$ and temperature under consideration, $T_{\mathrm{s}}=$ temperature at the point of inflection in $T_{\mathrm{g}}$ curve and $\mathrm{C}=$ constant. Plot of $\ln \left[-\ln (1-\alpha) / T^{2}\right]$ verses $-1 / T$ and $\ln \{\ln [1 /(1-\alpha)]\}$ against $\theta$ results in linear line with a slope of $E_{\mathrm{a}} / R$ and $\left(E_{\mathrm{a}} / R T_{\mathrm{i}}^{2}\right)$ $\left[100 /\left(T_{\mathrm{f}}-T_{\mathrm{i}}\right)\right.$ respectively (Figures 9 and 10). From the slope of these lines $E$, was calculated, and $A$ (Arrhenius constant) can be deduced from the intercept. The enthalpy of activation, $\Delta H$, and the free enthalpy of activation, $\Delta G$, can be calculated via the equations; $\Delta H=E-R T_{\mathrm{m}}$ and $\Delta G=\Delta H-T_{\mathrm{m}} \Delta S$ accordingly, and are shown in Table VI. The positive values of $\Delta H$ indicate that the dissociation processes are endothermic in nature and enhanced with the rise of temperature. $\Delta G$ values for the dissociation constants are positive, thus dissociation processes are non-spontaneous. The overall activation energy and entropy for thermal decomposition of PAs based on TDI is 110.43 and $-0.22 \mathrm{~kJ} \mathrm{~mol}^{-1}$ which is much higher than other PAs. This reveals that the more thermal stability and more ordered systems for this PA. One way to explain this behavior would be from the initial homolytic cleavage of $\mathrm{ph}-\mathrm{CH}_{3}$ bond which produces radical intermediate and therefore, provides a more stable cross-linked structure (Scheme 3). ${ }^{52}$ The other way to explain this performance would be due to electron releasing
(+I effect) property of methyl group which activates the amide linkages and makes them highly activated for hydrogen bonding formation.

\section{CONCLUSIONS}

In summary, molten $\mathrm{TBAB}$ may act as a simple, cheap (compare to the room temperature ILs) and safe medium for polymerization reactions. The reported procedure for the polycondensation of new monomer 7 with various diisocyanates under green conditions demonstrates the potential of molten TBAB, a benign readily available IL as an efficient media and has much promise for further applications. Moreover, this methodology offers significant improvements with regard to yield of products, inherent viscosities, thermal stability, simplicity in operation, cost efficiency and green aspects avoiding toxic solvents. Moreover, the use of any organic solvent was not needed throughout the whole process of polymerization; in fact, organic solvent removal is of importance to minimize economic cost and environmental impact of chemical processes. A comparable result on the isolated yields and inherent viscosities was obtained by microwave irradiation verses thermal heating with remarkable reduction in reaction time. The incorporation of naphthalimide and S-valine groups, through an amide unit into PAs backbone gave polymers with remarkable solubility in common organic solvents. Because of the existence of amino acids in the 


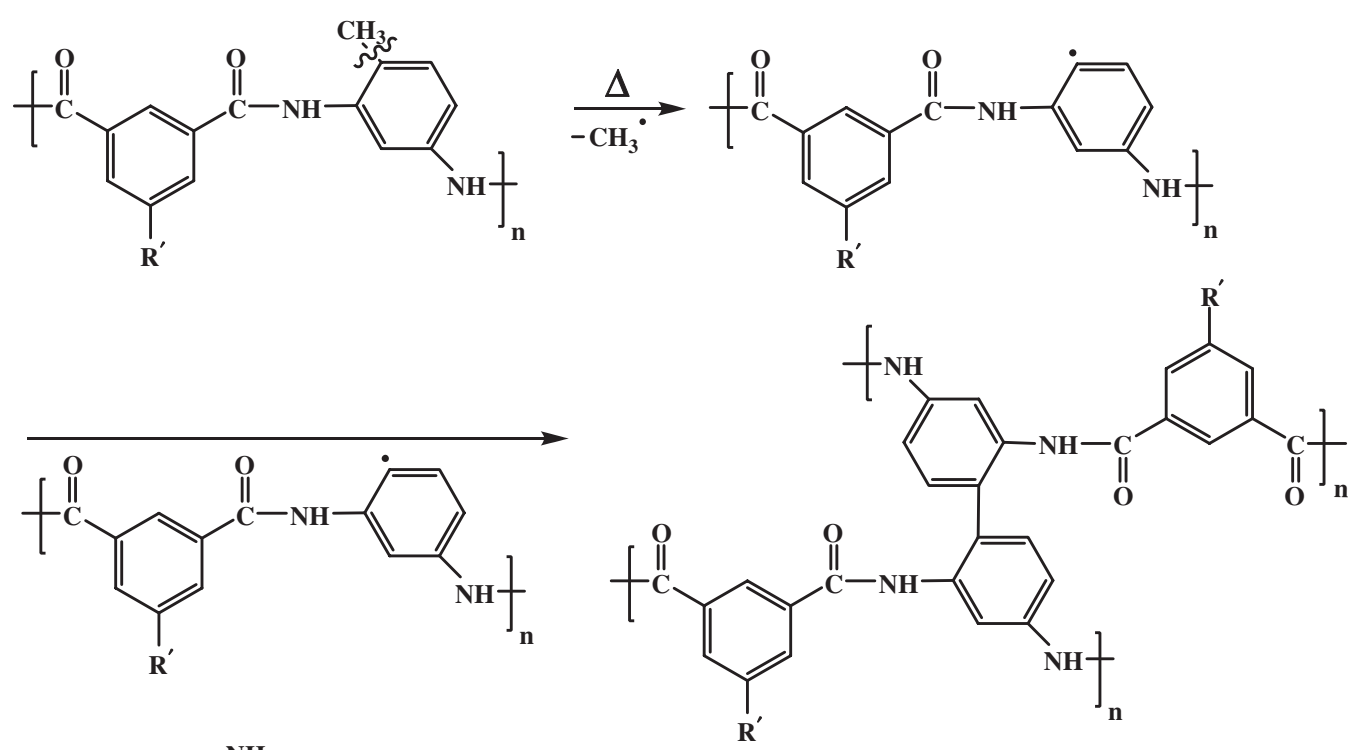<smiles></smiles>

Scheme 3.

polymer pendent group these polymers are expected to be biodegradable and are therefore classified under environmentally friendly polymers. The thermal degradation of PAs was analyzed using Coats-Redfern and Dharwadkar-Kharkhanawala methods. The corresponding kinetic parameters were calculated to well interpret the relationship between the composition of PAs and their stability. Furthermore, it is very interesting to mention that in this study the data obtained by two above different methods will lead us to predict the reaction mechanism of thermal degradation of the resulting PAs.

Acknowledgments. We wish to express our gratitude to the Research Affairs Division Isfahan University of Technology (IUT), Isfahan, for partial financial support. Further financial support from Center of Excellency in Sensors and Green Chemistry Research (IUT) is gratefully acknowledged. We also extend our thanks to Miss. Marziyeh khani and Zahra rafiee for the helpful assistance.

Received: February 20, 2008 Accepted: July 27, 2008 Published: September 11, 2008

\section{REFERENCES}

1. M. Poliakoff, J. M. Fitzpatrick, T. R. Farren, and P. T. Anastas, Science, 297, 807 (2002).
2. T. Biedroń and P. Kubisa, Polym. Int., 52, 1584 (2003).

3. B. C. Ranu, S. S. Dey, and A. Hajra, Tetrahedron, 59, 2417 (2003).

4. C. Amantini, F. Fringuelli, F. Pizzo, and L. Vaccaro, J. Org. Chem., 66, 6734 (2001).

5. S. Mallakpour and E. Kowsari, J. Polym. Sci., Part A: Polym. Chem., 41, 3974 (2003).

6. M. Tamada, T. Hayashi, and H. Ohno, Tetrahedron Lett., 48, 1553 (2007).

7. S. Harrisson, S. R. Mackenzie, and D. M. Haddleton, Macromolecules, 36, 5072 (2003).

8. H. Xie, S. Zhang, and H. Duan, Tetrahedron Lett., 45, 2013 (2004).

9. T. Fischer, A. Sethi, T. Welton, and J. Woolf, Tetrahedron Lett., 40, 793 (1999).

10. D. W. Morrison, D. C. Forbesa, and J. H. Davis, Tetrahedron Lett., 42, 6053 (2001).

11. Y. Peng and G. Song, Tetrahedron Lett., 45, 5313 (2004).

12. H. Zhang, K. Hong, and J. W. Mays, Macromolecules, 35, 5738 (2002).

13. V. Calò, A. Nacci, A. Monopoli, L. Lopez, and A. D. Cosmo, Tetrahedron, 57, 6071 (2001).

14. B. C. Ranu and S. S. Dey, Tetrahedron Lett., 44, 2865 (2003).

15. V. Calò, A. Nacci, L. Lopez, and V. L. Lerario, Tetrahedron Lett., 41, 8977 (2000).

16. S. Mallakpour and E. Kowsari, J. Appl. Polym. Sci., 101, 455 (2006).

17. S. Mallakpour and E. Kowsari, Polym. Eng. Sci., 46, 558 (2006).

18. F. Sanda and T. Endo, Macromol. Chem. Phys., 200, 2651 (1999).

19. S. Mallakpour and E. Kowsari, J. Appl. Polym. Sci., 91, 2992 (2004).

20. T. W. Baughman and K. B. Wagener, Adv. Polym. Sci., 176, 1 (2005).

21. G. Wulff, Angew. Chem., Int. Ed., 28, 21 (1989).

22. S. Mallakpour and E. Kowsari, J. Appl. Polym. Sci., 96, 435 (2005).

23. Y. Okamoto, Prog. Polym. Sci., 25, 159 (2000).

24. L. Feng, J. Hu, Z. Liu, F. Zhao, and G. Liu, Polymer, 48, 3616 (2007). 
25. C. O. Kappe, Angew. Chem., Int. Ed., 43, 6250 (2004).

26. S. Mallakpour and Z. Rafiee, Polymer, 48, 5530 (2007).

27. S. Mallakpour and F. Rafiemanzelat, J. Appl. Polym. Sci., 98, 1781 (2005).

28. F. Wiesbrock, R. Hoogenboom, and U. S. Schubert, Macromol. Rapid Commun., 25, 1739 (2004).

29. K. Ding, Z. Miao, Z. Liu, Z. Zhang, B. Han, G. An, S. Miao, and Y. Xie, J. Am. Chem. Soc., 129, 6362 (2007).

30. U. Hakala and K. Wähälä, J. Org. Chem., 72, 5817 (2007).

31. S. Mallakpour and Z. Rafiee, Eur. Polym. J., 43, 5017 (2007).

32. S. Mallakpour and E. Kowsari, Iran. Polym. J., 15, 239 (2006).

33. S. Mallakpour and E. Kowsari, Iran. Polym. J., 14, 81 (2005).

34. M. Onciu, J. Appl. Polym. Sci., 103, 2013 (2007).

35. L. Akcelrud, Prog. Polym. Sci., 28, 875 (2003).

36. Q. Xuhong, T. Jun, Z. Jiandong, and Z. Yulan, Dyes Pigm., 25, 109 (1994).

37. E. R. Simas and L. Akcelrud, J. Lumin., 105, 69 (2003).

38. W. Adam, X. Qian, and C. R. Saha-Moeller, Tetrahedron, 49, 417 (1993).

39. S. H. Hsiao and K. H. Lin, J. Polym. Sci., Part A: Polym. Chem., 43, 331 (2005).

40. S. H. Hsiao, Y. M. Chang, H. W. Chen, and G. S. Liou, J. Polym. Sci.,
Part A: Polym. Chem., 44, 4579 (2006).

41. Z. Ge, S. Yang, Z. Tao, J. Liu, and L. Fan, Polymer, 45, 3627 (2004).

42. D. J. Liaw, J. Polym. Sci., Part A: Polym. Chem., 43, 4559 (2005).

43. E. Ferrero, J. F. Espeso, J. G. Campa, J. D. Abajo, and A. E. Lozano, J. Polym. Sci., Part A: Polym. Chem., 40, 3711 (2002).

44. V. Calderón, F. García, J. L. De la Peña, E. M. Maya, Á. E. Lozano, J. G. de la Campa, J. de Abajo, J. Miguel García, J. Polym. Sci., Part A: Polym. Chem., 44, 4063 (2006).

45. S. Mallakpour and M. Taghavi, Polymer, 49, 3239 (2008).

46. D. W. Van Krevelen and P. J. Hoftyzer, "Properties of Polymers," 3rd ed., Elsevier Scientific Publishing, 1976.

47. C. T. Vijayakumar, P. Sivasamy, and T. Rajkumar, Eur. Polym. J., 43, 3028 (2007).

48. P. Sivasamy, M. Meenakshisundaram, and C. T. Vijayakumar, $J$. Anal. Appl. Pyrolysis, 68-69, 51 (2003).

49. A. W. Coats and J. P. Redfern, Nature, 201, 68 (1964).

50. Y. Chen and Q. Wang, Polym. Degrad. Stab., 92, 280 (2007).

51. M. N. Radhakrishnan Nair, G. V. Thomas, and M. R. Gopinathan Nair, Polym. Degrad. Stab., 92, 189 (2007).

52. V. L. Rao, P. U. Sabeena, A. Saxena, C. Gopalakrishnan, K. Krishnan, P. V. Ravindran, and K. N. Ninan, Eur. Polym. J., 40, 2645 (2004). 